\title{
Simulation of a long term atmospheric corrosion process on plain and weathering steels
}

\author{
F. Bolivar", A. Morales"*** and C. Arroyave*
}

\begin{abstract}
Information on weathering steel behaviour and its rust products characteristics after decades of atmospheric exposure are scarce. On the other side, generally accepted laboratory tests for the assessment of its corrosion resistance have not been developed yet. Consequently, simulating corrosion in the laboratory during long periods of time are attractive for the interesting and complete information obtainable from them. In the present work, AISI-SAE 1008 and ASTM-588 B steel samples have been exposed for two years to a immersion-emersion CEBELCOR type test in the laboratory, simulating a moderate urban atmosphere. Two groups of six samples each were tested. After the first year, three samples of each batch were retired for analysis and the rest was kept until they reached two years of exposure. The half cell electrode potentials were measured daily. The rust was characterized by metallographic techniques, Mössbauer spectroscopy (MS), Fourier transform infrared spectroscopy (FTIR), and X-ray diffraction (XRD). Comparison was done with field exposure experiments reported in the literature, and conclusions on the behaviour of tested samples were drawn looking for differences and similarities with samples and structures under actual atmospheric conditions.
\end{abstract}

Keywords Low-alloy steel. Rust. Mössbauer spectroscopy. Iron oxides. Immersionemersion test.

\section{Simulación de los procesos de corrosión atmosférica durante largos períodos de tiempo de un acero autoprotector $y$ ordinario}

Resumen La información sobre el comportamiento y las características de los productos de corrosión de los aceros auto protectores, después de varias décadas de exposición a la atmósfera, es escasa. Por otra parte, aún no se han desarrollado ensayos de laboratorio de aceptación general para evaluar su resistencia a la corrosión. En consecuencia, cada día toman más importancia los ensayos de laboratorio durante largos periodos de exposición. En el presente trabajo, se sometieron muestras de acero AISI -SAE 1008 y ASTM 588-B, durante dos años, a un ensayo de laboratorio de inmersión-emersión tipo CEBELCOR. Se ensayaron dos grupos de seis muestras de cada composición de acero, en una disolución que trataba de simular una atmósfera urbana moderada. Después del primer año, se retiraron tres muestras de cada grupo y el resto se dejo en el ensayo hasta completar los dos años exposición. Diariamente, se midió el potencial de electrodo respecto al electrodo de Calomel saturado. Las herrumbres formadas se caracterizaron mediante microscopía óptica, espectroscopía Mössbauer e infrarroja con transformada de Fourier y difracción de rayos X. Se realizó una comparación de los resultados obtenidos en este experimento con los reflejados en la literatura y se formularon conclusiones respecto a las diferencias y similitudes en su comportamiento.

Palabras clave Aceros de baja aleación. Herrumbre. Espectroscopía Mössbauer. Óxidos de hierro. Ensayos de inmersión-emersión.

(*) Corrosion and Protection Group, University of the Antioquia, P.O Box 1226, Medellin, Colombia.

(**) Department of Physics, University of Antioquia, P.O. Box 1226, Medellin, Colombia. 


\section{INTRODUCTION}

Weathering steels (WS) appeared approximately forty years ago, like an alternative to prevent the atmospheric corrosion of the structural steels. They are low-alloy steels, generally containing a mixture of elements such as copper, chromium, nickel, phosphorus, and silicon, with the resulting good mechanical properties, but, mainly, with a characteristic adherent and protective rust layer, developed during long-term exposure to atmospheres containing $\mathrm{SO}_{2}$. Consequently, WS is used in outdoor conditions, without the need for paint or other protective coatings. Because of its advantages over painted steel and concrete, its use in highway bridges in the United States, is increasing currently at an annual rate of c.a. 17 per cent $^{[1]}$. Also, in Japan, construction of bridges using WS in the unpainted condition increased sharply in the last two decades, and consequently, about 20 per cent of the steel bridges constructed in recent years used WS, accounting for an annual consumption of WS of about 50.000 tons $^{[2]}$.

Although the behaviour of the WS is widely known, the underlying mechanisms are not completely understood. One of the main reasons for this lack of knowledge is related with the absence of practical and generally accepted laboratory tests as a support for the study of WS and, consequently, many years of outdoor testing are needed to obtain new relevant information for the understanding of the mechanisms of protection and the development of new grades of WS. An alternative to the estimation of the long-term behaviour are the empirical equations deduced for the corrosion rate according to the WS composition $^{[3]}$ and the subsequent index proposed by ASTM G101 ${ }^{[4]}$.

Several years ago, morphological, chemical and electrochemical features, including good stratification, higher density and adherence, and the presence of some of the alloying elements in the rust layer were identified as the responsible of the better behaviour of WS over carbon steel (CS). As a similarity, the same constituents, including lepidocrocite $(\gamma-\mathrm{FeOOH})$, goethite $(\alpha-\mathrm{FeOOH})$, akaganeite $(\beta$ - $\mathrm{FeOOH})$, magnetite $\left(\mathrm{Fe}_{3} \mathrm{O}_{4}\right)$, and some other crystalline and amorphous iron oxihydroxides and oxides were identified in both the steels $^{[5-7]}$.

More recent work on long-term outdoor exposure of WS have confirmed a lot of the above mentioned characteristics, including the fact that nearly all the layers formed during more than 15 years, display similar structures when viewed in microscopic cross sections. They generally consist of alternating layers of goethite and lepidocrocite, plus some scattered patches of either magnetite or maghemite ${ }^{[8]}$.

Taking into account the significance of the above mentioned tests and, on the other side, their non-practical long exposure requirements, laboratory simulated experiments emerge like a very attractive alternative. Consequently, wet/dry chamber procedures look like a good possibility, if the importance of that cycle on the WS behaviour is recognised $\mathrm{d}^{[9}$ and 10] .

As a tool to perform good rust simulations in the laboratory, the immersion-emersion CEBELCOR technique has been known for several years ${ }^{[11]}$. Using this technique, very good simulations of the actual corrosion process at an specific site, can be done using cyclic immersionemersion test in an artificial solution with the basis characteristic composition of the rain water at the same place. Multiplication factors can be calculated, and decades of actual exposure can be simulated by more reasonable periods of time.

\section{EXPERIMENTAL PROCEDURE}

A conventional CEBELCOR immersionemersion chamber was used, and the following specific characteristics were fixed: $45 \mathrm{~min}$ per revolution, $13 \mathrm{~min}$. immersion by $32 \mathrm{~min}$. emersion relationship, drying temperature c.a. $328 \mathrm{~K}$, and a $1 \times 10^{-4} \mathrm{M} \mathrm{SO}_{4}{ }^{2-}$ corrosive solution, according to the mean concentration in the rain water of the moderately polluted Medellín, Colombia, atmosphere ${ }^{[12]}$. The multiplication factor for the same assembly, with AISI-SAE 1008 CS probes had been calculated in a previous work as $1: 10^{[13]}$.

Six samples of each steel, a very low CS and a typical ASTM A 588 B WS, with the compositions showed in table I, were exposed to the above mentioned conditions for two years, with a retirement at the end of the first and second years. The half cell electrode potentials were measured daily.

Then, rust characterisation by Mössbauer spectroscopy at room temperature, as one of the more proper techniques for this subject ${ }^{[14]}$, was done. Also, complementation with metallographic analysis under polarised light (Nikon Epiphot 200 microscope coupled to a Leica 500MC image 
Table I. Composition of the CS and the WS samples tested

Tabla I. Composición de las muestras CS y WS ensayados

\begin{tabular}{|c|c|c|c|c|c|c|c|c|c|c|c|c|}
\hline \multirow[t]{2}{*}{ Steel } & \multicolumn{12}{|c|}{ Composition (\%) } \\
\hline & $\mathrm{C}$ & $M n$ & $\mathrm{Si}$ & $\mathrm{P}$ & $S$ & $\mathrm{Ni}$ & $\mathrm{Cr}$ & $\mathrm{Cu}$ & Mo & $\mathrm{Al}$ & Sn & $\mathbf{V}$ \\
\hline CS & 0.02 & 0.28 & 0.00 & 0.025 & 0.019 & 0.02 & 0.00 & 0.01 & 0.005 & 0.001 & 0.006 & 0.016 \\
\hline wS & 0.10 & 1.19 & 0.95 & 0.021 & 0.011 & 0.04 & 0.63 & 0.29 & 0.013 & 0.025 & 0.006 & 0.036 \\
\hline
\end{tabular}

analyser), FTIR (Perkin-Elmer spectrometer operating in transmission mode, with $\mathrm{KBr}$ optics, in the 250-4000 $\mathrm{cm}^{-1}$ region), and XRD (RigakuMiniflex 2005 difractometer, equipped with a Cu$\mathrm{K} \alpha$ cathode and $\mathrm{Ni}$ filter), was done, assessing the outer and loose, and the inner and adherent sublayers, separately, when it was possible.

\section{RESULTS AND DISCUSSION}

Significant differences were observed in the behaviour of the two steels. In figure 1, it is observed that CS presents a very irregular behaviour of the potential, showing strong oscillations as a function of time; this can be associated with periodical disintegration of the rust layer on the CS; also, the potential is moving toward negative values, indicating the formation of a magnetite type constituent ${ }^{[15]}$. The WS begins with a potential more negative that CS, due to a larger activity caused by the alloy elements, and moves quickly toward positive values, reaching an almost constant value, indicating a decrease of the corrosion process $^{[14]}$.

Figure 2 shows the final corresponding sketches of the microscopic CS and WS rust images. It can be concluded that the nature of the formed products is in agreement with the rust formed on real structures: the same constituents in both kinds of rust, an evident sub-layer structure on the WS, with the expected dark patches ${ }^{[8]}$ and an heterogeneous mixture on the CS. A higher magnetite content and a higher thickness in the CS rust, and a higher goethite content in the WS rust. The layer structures found are in agreement with the findings of Yamashita et al. for $\mathrm{WS}^{[8]}$ and Rendon $^{[13]}$ for CS. As can be seen in the WS image, there is essentially an internal goethite layer close to the steel surface, and an external lepidocrocite layer.

Tables II and III summarises results from the Mössbauer characterisation, including the measured hyperfine parameters, the identified constituents, and their relative amounts, after a

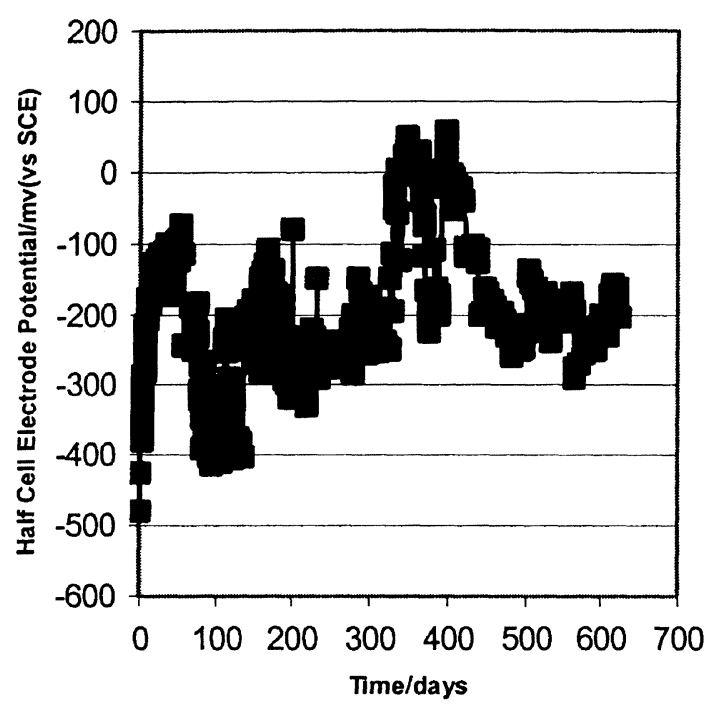

a)

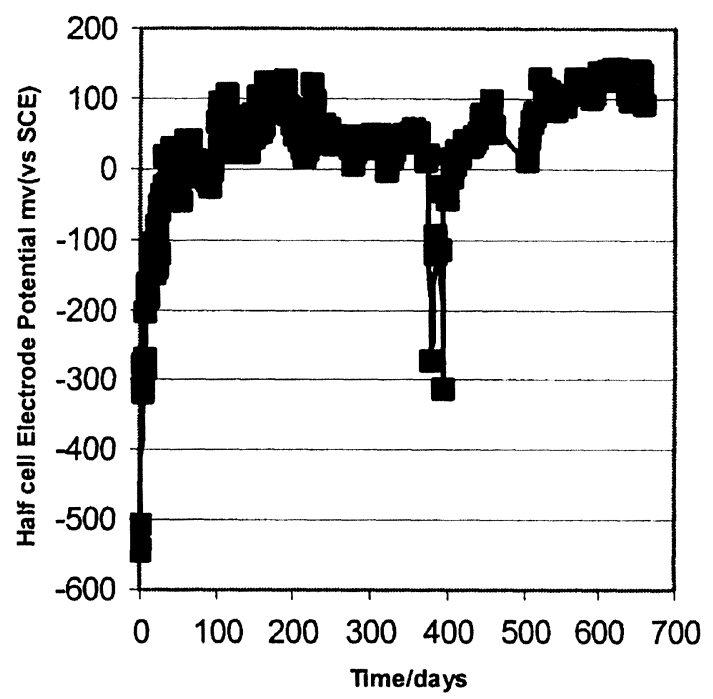

b)

Figure 1. Variation of the half cell electrode potential with time at, the entrance into the electrolyte, for CS(a) and WS (b).

Figura 1. Variación del potencial de electrodo de media celda a la entrada en el electrolito, para CS (a) y WS (b).

fitting with a non-linear least-squares procedure, assuming Lorentzian line shapes. More important conclusions on this subject are concerning with: i) the same basic constituents in both types of rust for 


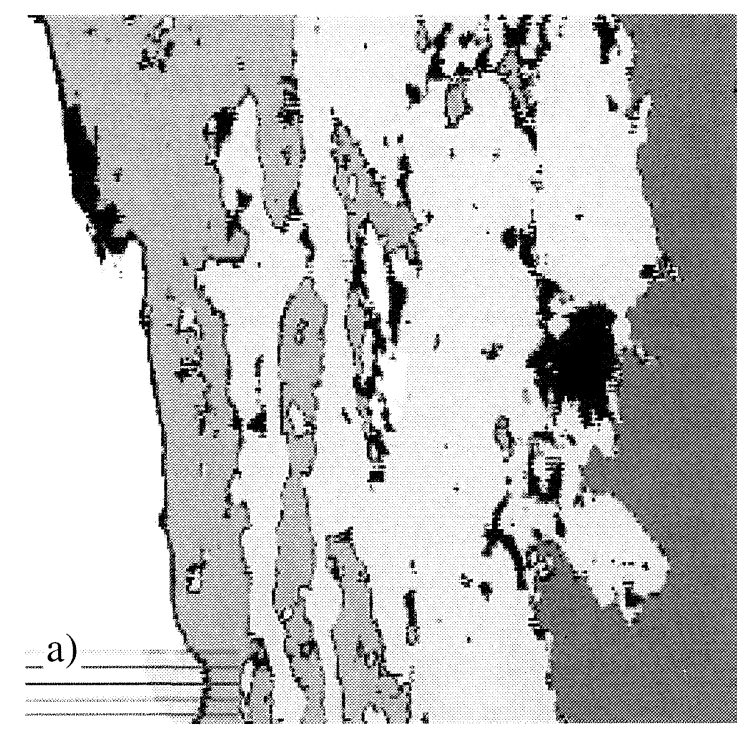

b)

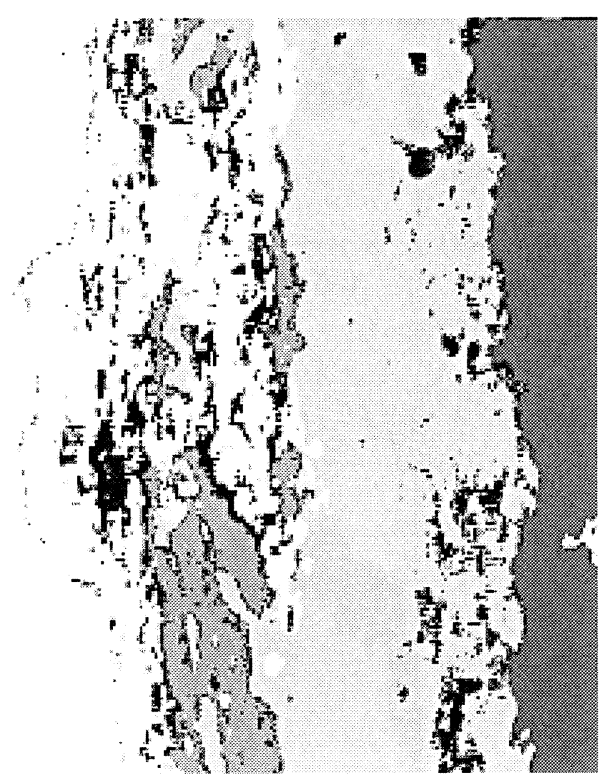

Figure 2. Sketches of the microscopic images. (a) CS and (b) WS. A gray scale convention, going from the clearest substrate steel, to goethite, lepidocrocite, magnetite, and mounting resin, as the darkest one, is used.

Figura 2. Imágenes microscópicas (a) CS y (b) WS. Una convención de escala de grises es usada, yendo del substrato de acero más claro, la goethita, lepidocrita, magentita, y la resina usada es la más oscura.

the same time of exposition, ii) there is a strong increment in the magnetite content, and a decrease in the goethite and paramagnetic species between the CS rust for one and two years of exposure to the CEBELCOR chamber, iii) the doublets in the spectra of all the samples are assigned to lepidocrocite and super-paramagnetic goethite, corroborated by XRD and FTIR (this doublet is the main component for the WS rust as can be expected from the complementary
Table II. Room temperature Mössbaver parameters and relative areas, the one year the exposition

Tabla II. Parámetros Mössbaver a temperatura ambiente y áreas relativas de las herrumbres después de un año de exposición

\begin{tabular}{llcccc}
\hline Sample & $\begin{array}{l}\text { Constituent } \\
\text { assignment }\end{array}$ & $\begin{array}{c}\text { H } \\
(\mathbf{k O e})\end{array}$ & $\begin{array}{c}\text { IS } \\
\left(\mathrm{mm} \mathrm{s}^{-1}\right)\end{array}$ & $\begin{array}{c}\text { QS } \\
\left(\mathrm{mm} \mathrm{s}^{-1}\right)\end{array}$ & $\begin{array}{c}\text { Area } \\
(\%)\end{array}$ \\
\hline \multirow{4}{*}{ CS - outer rust } & Magnetite A & 492 & 0.24 & -0.004 & 24.6 \\
& Gagnetite B & 457 & 0.55 & -0.02 & 13.9 \\
& Goethite & 327 & 0.27 & -0.27 & 27.8 \\
& Doublet 1 & & 0.19 & 0.50 & 7.1 \\
& Doublet 2 & & 0.31 & 0.57 & 26.6 \\
& Magnetite A & 492 & 0.21 & -0.03 & 23.3 \\
CS - inner rust & Magnetite B & 458 & 0.54 & 0.05 & 15.0 \\
& Goethite & 313 & 0.16 & -0.47 & 27.2 \\
& Doublet 1 & & 0.23 & 0.47 & 18.8 \\
& Doublet 2 & & 0.32 & 0.58 & 15.7 \\
& Magnetite A & 495 & 0.26 & 0.0 & 5.8 \\
WS & Magnetite B & 465 & 0.66 & 0.0 & 4.1 \\
& Goethite & 296 & 0.34 & -0.27 & 14.1 \\
& Doublet 1 & & 0.30 & 0.57 & 67.0 \\
& Doublet 2 & & 0.10 & 0.51 & 9.0
\end{tabular}

Table III. Room temperature Mössbauer parameters and relative areas, the two year the exposition

Tabla III. Parámetros Mössbauer a temperatura ambiente y las áreas relativas de las herrumbres después de dos años de exposición

\begin{tabular}{llcccc}
\hline Sample & $\begin{array}{l}\text { Constituent } \\
\text { assignment }\end{array}$ & $\begin{array}{c}\mathrm{H} \\
(\mathbf{k O e})\end{array}$ & $\begin{array}{c}\text { IS } \\
\left(\mathrm{mm} \mathrm{s}^{-1}\right)\end{array}$ & $\begin{array}{c}\text { QS } \\
\left(\mathrm{mm} \mathrm{s}^{-1}\right)\end{array}$ & $\begin{array}{c}\text { Area } \\
(\%)\end{array}$ \\
\hline \multirow{4}{*}{ CS } & Magnetite A & 491 & 0.19 & 0.00 & 37.2 \\
& Magnetite B & 457 & 0.47 & 0.00 & 31.5 \\
& Goethite & 300 & 0.16 & -0.27 & 19.9 \\
& Doublet 1 & & 0.23 & 0.55 & 11.4 \\
\multirow{4}{*}{ WS } & Magnetite A & 481 & 0.15 & 0.0 & 13 \\
& Magnetite B & 450 & 0.55 & 0.0 & 10.2 \\
& Doublet 1 & & 0.26 & -0.60 & 76.8 \\
& & & & &
\end{tabular}

techniques used) and, iv) for the two years CS rust, the clearest sign is that of magnetite, also goethite and lepidocrocite are present in smaller amounts.

FTIR and XRD results revealed the presence of the constituents reported in table IV. Both types of the more eminent features are in close agreement with the above results, with some special characteristics to be mentioned: the obvious $\mathrm{SO}_{4}{ }^{2-}$ presence, but higher in the WS rust, simultaneously with a higher water content.

XRD results are in agreement with MS and FTIR. In the two years CS samples is observed an 
Table IV. Summary of FTIR and XRD results

Tabla IV. Resumen de los resultados de FTIR y XRD

\begin{tabular}{|c|c|c|}
\hline \multirow[t]{2}{*}{ Steel } & \multicolumn{2}{|c|}{ Main features } \\
\hline & XRD & FTIR \\
\hline CS-outer rust-one year & $\begin{array}{l}\text { Strong evidence of abundant lepidocrocite } \\
\text { and evidence of magnetite, too. }\end{array}$ & $\begin{array}{l}\text { Strong evidence of lepidocrocite, evidence goethite } \\
\text { and magnetite. Important presenc of oxyhydroxides. } \\
\text { Presence of } \mathrm{SO}_{4}^{-2} \text {. }\end{array}$ \\
\hline CS-inner rust-one year & $\begin{array}{l}\text { Evidence of lepidocrocite and magnetite. } \\
\text { Maybe goethite. }\end{array}$ & The same than the outer sub-layer. \\
\hline CS-two years & $\begin{array}{l}\text { Evidence of magnetite and goethite } \\
\text { maybe lepidocrocite. }\end{array}$ & Evidence of lepidocrocite, goethite and magnetite. \\
\hline WS one year & $\begin{array}{l}\text { Clear evidence of lepidocrocite, scarce } \\
\text { magnetite, and maybe goethite (see text). }\end{array}$ & $\begin{array}{l}\text { Strong evidence of lepidocrocite, maybe goethite } \\
\text { and magnetite. Important presenc of oxi-hydroxides, } \\
\text { water and } \mathrm{SO}_{4}^{-2} \text {. }\end{array}$ \\
\hline WS two years & $\begin{array}{l}\text { Clear evidence of lepidocrocite, scare } \\
\text { goethite (see text) and magnetite. }\end{array}$ & $\begin{array}{l}\text { Evidence of lepidocrocite, maybe goethite and } \\
\text { magnetite. }\end{array}$ \\
\hline
\end{tabular}

increment in the intensity of the magnetite peaks and a decrease of the peaks of lepidocrocite. With regard to WS, the spectrum it is very similar for both samples, showing more intense peaks for lepidocrocite and weak peaks for goethite and magnetite. The small peak intensity for goethite is due to its form of nano-particles so showing broad and small peaks but its amount in the WS rust is large as can be seen from the results of MS, FTIR, and microscopy images.

\section{CONCLUSIONS}

The results showed a good agreement with the reported features for WS. Thus, it is possible to say that:

- Differences between CS and WS were evidently marked.

- Half cell electrode potentials were in good agreement with the reported results, and with the proposed rust formation mechanisms.

- The assessed rust characteristics were in direct relation with the reported results from long term exposure conditions in the field.

- All the evidences show that the constitution of the rust formed on the WS, is equivalent to the rust reported for the same material exposed during decades to actual $\mathrm{SO}_{2}$ polluted atmospheres.

- Consequently, corrosion studies in the laboratory, such as the wet/dray methods, can support the current research on conventional WS and, mainly, in the development of new steels.

\section{Acknowledgements}

Authors thank Mr. Alberto Zapata for the images processing.

\section{REFERENCES}

[1] C.G. RubeIz, AISI Weathering Steel Bridge Survey, American Iron and Steel Institute, Washington, U.S.A., 1998.

[2] I. Matsushima, Corros. Prot. Steel. 139 (1997).

[3] H.E. Townsend, Proc. $14^{\text {th }}$ International Corrosion Congress, Cape Town, South Africa, 1999.

[4] www.astm.org./cgi-bin/SoftCart.exe/COMMIT/ COMMITTEE/G01

[5] H. OKadA et al., Proc. $4^{\text {th }}$ International Congress of Metallic Corrosion, Amsterdam, Holland, 1969.

[6] T. Misawa et al., Corros. Sci. 11 (1971) 35.

[7] L.R.M. MiRAnda, Theses, Université Libre de Bruxelles, Bruxels, 1974.

[8] M. YAmASHITA et al., ISIJ Int. 38 (1998) 285.

[9] J.H. WANG et al., Corrosion 52 (1996) 600.

[10] J.H. Wang et al., Corrosion 52 (1996) 900.

[11] M. Pourbaix et al., Atmospheric Corrosion, W.H. Ailor (Ed.), Wiley, New York, U.S.A., 1982, p. 167.

[12] J. Calderón, M.Sc. Theses, University of Antioquia, Medellin, Colombia, 1999.

[13] J.L. RENDÓN, M.Sc. Theses, University of Antioquia, Medellin, Colombia, 1997.

[14] S.J. OH, D.C. COOK and H.E. Townsend, Hyp. Interact. 112 (1998).

[15] J.L. Rendón et al., Phys. Status Solidi (B) 220 (2000) 351. 


\section{PRESENTACIÓN DE TRABAJOS A REVISTA DE METALURGIA}

\section{INSTRUCCIONES TÉCNICAS PARA LOS AUTORES}

Revista de Metalurgia es una publicación de ámbito internacional sobre ciencia y tecnología de materiales metálicos, cuyo principal objetivo es contribuir a la difusión de los nuevos conocimientos científicos y desarrollos tecnológicos que se producen en este campo. En ella, se recogen principalmente trabajos sobre los procedimientos de obtención, fabricación, transformación y reciclado de metales y aleaciones, las propiedades y características tecnológicas de los mismos, así como las diferentes aplicaciones de estos materiales.

Revista de Metalurgia es una publicación del Centro Nacional de Investigaciones Metalúrgicas, perteneciente al Consejo Superior de Investigaciones Científicas.

\section{TIPO DE TRABAJOS}

1.1. Originales. Contribuciones en las que se describan y discutan los resultados de trabajos de I+D o de experiencias industriales de interés.

1.2. Revisiones. Revisiones bibliográficas o críticas sobre el conocimiento actual en campos específicos de ciencia y tecnología metalúrgicas.

1.3. Notas técnicas. Trabajos en los que se describan experiencias prácticas sobre procedimientos de laboratorio y de taller técnicas de ensayo y caracterización, comportamiento en servicio de los materiales, aplicaciones industriales, etc.

1.4. Comunicaciones. Contribuciones breves en las que se informe o se adelanten resultados.

\section{PRESENTACIÓN DE LOS ORIGINALES}

\subsection{Envío de los trabajos}

\subsubsection{Envío postal}

Los trabajos se enviarán a la Redacción en soporte papel (copia impresa), acompañados de las figuras originales y una copia de las mismas, además de una copia en un disquete de 3,5" (formateado para $\mathrm{PC}$ ) o un CD-ROM, conteniendo todo el trabajo.

La dirección correcta para los envíos es:

\section{Revista de Metalurgia \\ Redacción. CENIM \\ Avda. de Gregorio del Amo, 8 \\ 28040 Madrid (España)}

Los trabajos irán acompañados de una carta original en la que se solicitará la publicación del trabajo y se indicará la dirección completa del autor al que debe dirigirse toda correspondencia relacionada con el mismo.

\subsubsection{Envío electrónico}

También se admitirán trabajos remitidos por correo electrónico, que siempre deberán incluirse en un fichero adjunto al mensaje de presentación de los mismos. En este caso, en el transcurso del proceso de edición, el autor deberá hacer llegar a la Redacción, en soporte papel, la carta original firmada en la que solicita la publicación del trabajo, así como las fotografías, figuras e ilustraciones originales y una copia de las mismas.

La dirección electrónica es:

\section{revista@cenim.csic.es}

\subsection{Originalidad, lenguaje y estilo}

Se presentarán exclusivamente trabajos originales que no hayan sido editados anteriormente en ningún tipo de publicación.

Aunque los trabajos deberán redactarse en español o en inglés, el título, que debe reflejar el contenido del trabajo, debe redactarse en ambos idiomas. A continuación, debe figurar el nombre completo de cada uno de los autores del trabajo seguido del primer apellido (en el caso de desear que figuren dos apellidos, separarlos por un guión).

El resumen debe redactarse también en español y en inglés y debe describir el contenido del trabajo en 150 palabras como máximo. Al final del resumen se incluirán cinco palabras clave, en español y en inglés.

No debe duplicarse la presentación de datos mediante su inserción en figuras y tablas.

El texto del trabajo debe dividirse en secciones y subsecciones numeradas. Las páginas deben numerarse correlativamente.

Las referencias, ecuaciones, tablas y figuras deben numerarse correlativamente según su inserción en el texto (las referencias entre corchetes [1], [2], [3-6]..., las ecuaciones entre paréntesis, como (1), (2), (3)..., las tablas con números romanos, como I, II, III...y las figuras como Fig. 1, Fig. 2, Fig. 3...).

\subsection{Presentación de trabajos}

\subsubsection{En soporte papel}

La extensión del texto escrito de los trabajos originales remitidos no superará las 25 páginas a doble espacio, excluido el espacio ocupado por tablas y figuras.

Además del texto, debe aparecer en páginas separadas cada uno de los apartados siguientes:

a) El título en español y en inglés, seguido por los nombres y las direcciones de los autores.

b) El resumen y las palabras clave (en español y en inglés).

c) Las referencias bibliográficas.

d) Cada una de las figuras.

e) La relación de todos los pies de las figuras (en español y en inglés).

f) Cada una las tablas con su correspondiente cabecera en español y en inglés.

g) Los posibles agradecimientos.

\subsubsection{En soporte informático}

Es obligatorio enviar una copia electrónica que contenga el fichero del texto del trabajo original, en un disquete de ordenador PC $\left(3,5^{\prime \prime}\right)$, un CD-ROM o por correo electrónico. Además, deben adjuntarse, si es posible, los ficheros que correspondan a las figuras, fotografías e ilustraciones que lo acompañan. Los ficheros de texto corresponderán a procesadores de uso universal (preferentemente Word 97) y serán remitidos en formato de texto (.doc), a ser posible no comprimido. Para los ficheros gráficos o de imagen se indicará el programa con que pueden abrirse. En todo caso, en el mensaje de presentación del trabajo, debe especificarse claramente el formato de cada uno de los ficheros de texto o gráficos, el tipo de fichero, la extensión de los mismos y los programas con que están creados y modificados. Para más detalles, los autores pueden dirigirse a la Redacción de la Revista.

\subsection{Referencias bibliográficas}

Las referencias bibliográficas aparecerán insertadas en el texto en orden correlativo, con el número correspondiente escrito entre corchetes $y$, preferentemente, como superíndice $\left({ }^{1}\right)$ ya que así serán publicadas. Al final del trabajo, en una hoja separada, deben relacionarse todas, correlativamente, con los datos y la puntuación que se indica a continuación:

\subsubsection{Criterios generales}

Todos los datos de las referencias son obligatorios. En los parágrafos siguientes se indican cuáles son aquellos, según el tipo de publicación. Los ejemplos muestran el formato y las características tipográficas que deben aplicarse a cada dato y a la notación de separación entre los mismos. Es recomendable que las referencias incluidas en los trabajos se expresen del mismo modo.

No deben incluirse referencias a comunicaciones confidenciales o a publicaciones restringidas que no sean fácilmente accesibles para los lectores. 
En el caso de que deban figurar dos apellidos de un autor, se indicarán separándolos por un guión.

Deben indicarse, habitualmente, los números de página inicial y final y separados por un guión. No se aceptarán referencias en las que no se incluya, al menos, el número de página inicial.

Las abreviaturas de los títulos de las revistas deben ajustarse a las incluidas en la norma UNE- 1008-77 (ISO 4-1972). A título orientativo, puede consultarse la guía Bibliographic Guide for Editors $\mathcal{E}$ Authors, que publica la American Chemical Society.

\subsubsection{Publicaciones periódicas}

Inicial(es) del nombre de cada autor seguido del primer apellido, título abreviado de la revista, volumen, número de fascículo o mes (si las páginas de los diferentes fascículos anuales no son continuadas), año de publicación, número de las páginas inicial y final.

\subsubsection{Libros o monografías}

Inicial(es) del nombre de cada autor seguido del primer apellido, título del libro, nombre de la editorial, número de edición, ciudad de la edición, país, año de publicación, número de las páginas inicial y final.

\subsubsection{Resúmenes (Actas, Proceedings) de congresos o conferencias}

Inicial(es) del nombre de cada autor seguido del primer apellido, título del congreso, volumen de los resúmenes, ciudad de la celebración, país, año de la celebración, nombre del editor(es), nombre de la editorial, ciudad de la edición, país, año de publicación, número de las páginas inicial y final.

\subsubsection{Tesis Doctorales}

Inicial(es) del nombre del autor seguido del primer apellido, Facultad, Universidad, año de calificación de la Tesis.

\subsubsection{Ejemplos}

[1] C. CORNEJO y J. GARCÍA-NÚÑEZ, Rev. Metal. Madrid 34 (1998) 235-239.

[2] F. R. MORRAL, E. JIMENO y P. MOLERA, Metalurgia General, Ed. Reverté, Barcelona, España, 1985, pp. 161-168.

[3] J. G. SMITH y R. H. JONES, Proc. ICSMA-8, vol. 2, Tampere, Finlandia, 1987, T. Thomas y R. Wilson (Eds.), Pergamon Press, Oxford, Inglaterra, 1988, pp. 131-136.

[4] L. ASENJO, Tesis Doctoral, Facultad de Ciencias Físicas, Universidad Complutense de Madrid, 1995.

\subsection{Ilustraciones, figuras y micrografías}

\subsubsection{Presentación}

Cada figura o ilustración debe presentarse en una hoja separada. Los pies de las mismas, redactados en español y en inglés, deben permitir una correcta interpretación de aquellas sin que sea preciso acudir al texto. Además, los pies de todas las figuras que aparezcan en el trabajo se relacionarán conjuntamente en hoja aparte y correlativamente. Las figuras deben ser de una calidad que permita una buena impresión. Es obligatorio enviar un juego de figuras originales $\$ una copia del mismo que se procurará sean de buena calidad para su correcta impresión. Las figuras que incluyen gráficos, en los que aparezcan ejes cartesianos no deben presentarse con trama de fondo, cuadrícula o sub-ejes, a no ser que sea imprescindible para interpretar la figura.

\subsubsection{Micrografias y fotografías}

Las micrografías, y en algunos casos las fotografías, deben especificar los aumentos por medio de una escala en el interior de las mismas. En casos excepcionales se podrá indicar los aumentos en el pie de figura, como en el ejemplo siguiente: " $\times 150$ ". Además, en el reverso de las mismas y escrito a lápiz, debe hacerse constar el nombre del autor y el número de figura.

\subsubsection{Color}

Las figuras, micrografías o fotografías serán editadas en blanco y negro aunque el original enviado sea de color. Sólo se publicarán en color cuando el autor, expresamente, acepte abonar los gastos extra ocasionados.

\subsubsection{Tamaño y colocación}

Las figuras se enviarán de un tamaño igual o mayor al de las dimensiones finales a las que aparecerá reproducido en la Revista. Estas dimensiones son: ancho de columna $(80 \mathrm{~mm})$ o ancho de página $(170 \mathrm{~mm})$. La altura final de las leyendas y expresiones de las figuras, tras la reducción correspondiente, debe ser de un mínimo de $3 \mathrm{~mm}$.

Cuando una figura esté formada por dos o más ilustraciones o micrografías relacionadas entre sí, de modo que todas las ilustraciones se correspondan con el mismo número de figura, se indicará cuál es la a), b), c),... mediante la inserción de la letra correspondiente en la figura.

\subsection{Tablas}

Las tablas deben llevar un encabezamiento, en español y en inglés, y deben ser inteligibles sin necesidad de acudir al texto. Las tablas no presentarán trama alguna y las divisiones horizontales y verticales de los datos se limitarán a las imprescindibles para la comprensión de los mismos.

\subsection{Unidades}

Tanto en el texto como en las ilustraciones sólo se utilizarán los símbolos y abreviaturas del Sistema Internacional de Unidades (SI). Como excepción se admitirá que las temperaturas se expresen en grados centígrados y los tiempos largos en horas.

\subsection{Pruebas de imprenta}

El autor con el que se mantenga la correspondencia sobre el trabajo recibirá, con carácter general, un juego de pruebas de imprenta para su verificación. En todo caso, se le solicitará la conformidad al texto final que haya sido preparado con las correcciones de los revisores o de la Redacción de la Revista antes de su envío a la imprenta. En esta etapa de la edición del trabajo no se admitirá la inclusión de material nuevo.

\subsection{Separatas y ejemplares impresos}

$\mathrm{Al}$ autor con el que se mantenga la correspondencia sobre el trabajo se le enviará tantos ejemplares del número de la Revista donde aparezca aquel como autores tenga el trabajo. Se pueden enviar separatas, a cargo de los autores y a los precios de costo de las mismas, siempre y cuando se haga constar al devolver, una vez corregidas, las pruebas de imprenta del trabajo.

\subsection{Devolución de fotografías y originales}

En el caso de rechazarse expresamente la publicación de un trabajo se devolverá el material original aportado a la Revista. Cuando el trabajo no llegara a publicarse por haber sido retirado por los autores en cualquiera de sus fases previas a la publicación, el material original sólo se devolverá por petición expresa recibida en los 30 días siguientes a la retirada.

\section{DERECHOS DE AUTOR}

$\mathrm{Al}$ remitir un trabajo, los autores acceden a que sus derechos sobre el mismo sean transferidos al editor siempre y cuando el mencionado trabajo sea aceptado para su publicación. Estos derechos de autor cubren los derechos en exclusiva para reproducir y distribuir el artículo en cualquier soporte y las traducciones del mismo. Con carácter general, no se devolverán a los autores ni los originales en soporte papel e informático, ni las figuras o ilustraciones originales correspondientes a los trabajos publicados. 